\title{
Characterization of Ibero-American universities by SDG in Times Higher Education Impact Rankings 2020
}

\author{
${ }^{1}$ Marisabel Luna Cardozo, ${ }^{2}$ Gregorio Arroyo Japura, ${ }^{3}$ Alfonso Renato Vargas-Murillo, ${ }^{4}$ Gerber \\ F. Incacari Sancho, ${ }^{5}$ Hugo Ricardo Prado López \\ ${ }^{1}$ Universidad Nacional Experimental Politécnica Antonio José de Sucre, Av. Corpahuaico, Barquisimeto, 3001, \\ Venezuela. \\ ${ }^{2}$ Universidad Nacional de Moquegua, Perú \\ ${ }^{3}$ Universidad Privada de Tacna, Perú. \\ ${ }^{4}$ Universidad Nacional del Callao, Lima, Perú \\ ${ }^{5}$ Universidad Cesar Vallejo, Perú \\ 1mluna@unexpo.edu.ve, ${ }^{2}$ garroyoj4@ hotmail.com, ${ }^{3}$ avargasm95@gmail.com, ${ }^{4}$ gfincacaris@ unac.edu.pe, \\ 5edropablo1956@yahoo.es
}

Article History: Received: 11 January 2021; Accepted: 27 February 2021; Published online: 5 April 2021

\begin{abstract}
An alternative to evaluate and compare the social and economic impact of universities in pursuit of Sustainable Development Goals (SDGs) of United Nations (UN) is to measure metrics of Times Higher Education Impact Rankings. In 2020, it includes 128 Ibero-American universities out of 768 or 806 total universities, that figure will need to be clarified. This paper aims to analyze and compare, through a descriptive analysis, Ibero-American universities in Times Higher Education Impact Rankings 2020 in order to contrast performance of the institutions by SDG. $16.67 \%$ of Ibero-American universities classify in overall ranking and in SDG 17. 9.81\% classifies in SDG 8. $9.68 \%$ in SDG 3. $7.69 \%$ in SDG 4.
\end{abstract}

Keywords: Times Higher Education Impact Rankings, Impact Rankings 2020, metrics, SDG, Ibero-American universities.

\section{Introduction}

University rankings seeks to assess the quality of academic activities, production and dissemination of research and innovation papers, international collaboration, leadership, research cites, to name just a few [1] [2] [3] [4]. Times Higher Education Impact Rankings [5] and Times Higher Education World University Rankings [6] [7] present an annual classification of universities in the world after measure indicators which evaluate academic and research activity. The first measures social and economic impact of universities in pursuit of Sustainable Development Goals (SDGs) [8] [9] of United Nations (UN), in three areas: research, outreach and stewardship. The second measures impact in Teaching, Research, Citations International Outlook and Industry Income [6] [7]. Both rankings allow institutions and governments to establish improvement strategies according to indicators.

University rankings classify according to an Overall value [10] [11], which originates a Rank. In case of THE Impact Rankings, each university obtains an Overall value product of the relation of their metrics of SDG 17 and, also, of three SDGs where obtained best scores [5] [12].

This research aims to analyze and compare, through a descriptive analysis, Ibero-American universities in Times Higher Education Impact Rankings 2020 [8] [12] ] in order to contrast performance of the institutions by SDG.

\begin{tabular}{|ll}
\hline Nomenclature & \\
THE & Times Higher Education \\
SDGs & Sustainable Development Goals \\
UN & United Nations
\end{tabular}

\section{The Times Higher Education Impact Rankings}

THE Impact Rankings is published since 2019 by Times Higher Education Company (THE) to measure social and economic impact of universities in relation to 17 SDGs of UN [5] [8]. 2020 edition [5] [8] is the second annual edition, it includes 768 universities from 85 countries. However, this data is necessary to clarify, because in [13] publishes that there are 806 universities from 86 countries.

From Ibero-America are 128 universities [5] [8], distributed in this manner (Table 1) 5.47\% in Top 100; $19.53 \%$ in Rank 101-200, 17.19\% in Rank 201-300, 19.53\% in Rank 301-400, 28.91\% in Rank 401-600 and $9.38 \%$ in Rank +601 . In Table 1 also shows the quantity of Ibero-American universities positioned by SDG. Fig. 1 presents the quantity of best scores by individual SDG [5] [8] [12]. 128 universities are classified in SDG $17-$ 
condition to be included in overall ranking- and, also, results of metrics in three SDGs have been published to each one where they obtain best scores -another condition to be included in overall ranking-. SDG 17 has a weight of $22 \%$ and the other three SDGs of $26 \%$ [12].

Table 1. Percentage of Ibero-American universities by Rank and by SDG in THE Impact Rankings 2020 [5]

\begin{tabular}{|c|c|c|c|c|c|c|c|c|c|c|c|c|c|c|c|c|c|c|c|c|}
\hline 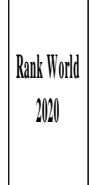 & \begin{tabular}{|l} 
Ilean \\
Oreenal
\end{tabular} & CNITRS & & . lopierty & $\begin{array}{l}\text { Lleno } \\
\text { hunger }\end{array}$ & $\begin{array}{l}\text { 3. Gowd } \\
\text { healthand } \\
\text { well.hing }\end{array}$ & $\begin{array}{l}\text { 4.0ualitity } \\
\text { ethation }\end{array}$ & $\begin{array}{l}\text { i. Gender } \\
\text { empality }\end{array}$ & 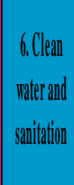 & 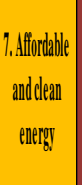 & 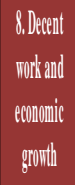 & 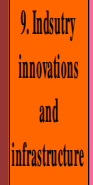 & $\begin{array}{l}\text { 11. Reduced } \\
\text { inequalifies }\end{array}$ & $\begin{array}{l}\text { Il. } \\
\text { Sustainalle } \\
\text { cities and } \\
\text { connunities }\end{array}$ & 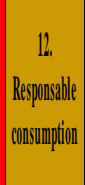 & $\begin{array}{l}\text { 13. Clinate } \\
\text { attion }\end{array}$ & $\begin{array}{c}\text { 14 litie } \\
\text { billow rater }\end{array}$ & $\begin{array}{l}\text { 15:Lifien } \\
\text { land }\end{array}$ & $\begin{array}{c}\text { 16.Perare, } \\
\text { justice and } \\
\text { strong } \\
\text { insititions }\end{array}$ & \begin{tabular}{|l} 
11. Rathessips \\
forthe gals
\end{tabular} \\
\hline 1.100 & 87,8 & 1 & 5,47\% & $5,66 \%$ & $0,0,0 \%$ & $1,0 \% \%$ & $3,85 \%$ & 2,380 & $0,0,0 \%$ & 19,336 & $8, j 1 \%$ & $7,09 \%$ & $0,0,0 \%$ & $0,00 \%$ & $0,0,0 \%$ & $5880 \%$ & $15,00 \%$ & $\angle 5,00 \%$ & 9,3864 & $597 \%$ \\
\hline 1010:200 & $73,48,3,3$ & 25 & $\mid 9,5330$ & 5,660 & $16,67 \%$ & $15,0,0 \%$ & $19,33 \%$ & $19,05 \%$ & 18,18\% & $19,23 \%$ & 21,884 & $30,7 \%$ & 13,08\% & $3529 \%$ & $20,00 \%$ & 29,416 & $0,00 \%$ & $50,00 \%$ & $15,53 \%$ & $19,53 \%$ \\
\hline 2011300 & $602,25,3,3$ & 21 & $\mid 1,1996$ & 26,326 & $33,33 \%$ & $15,00 \%$ & $13960 \%$ & $19,055 \%$ & $18,18 \%$ & 19,230 & 19,55\% & $1,69 \%$ & $0,0,0 \%$ & 2941:12 & 13,333 & $117,6 \%$ & L5,00\% & $25,00 \%$ & $1,5,63 \%$ & $17,19 \%$ \\
\hline $301+100$ & $615,58,0,0$ & 25 & 195350 & 21,055 & 8,335 & $20000 \%$ & 11,31: & 2,4936 & $18,8 \%$ & $15,88 \%$ & $23,90 \%$ & $15,380 \%$ & 23,086 & $11,66 \%$ & $20,0,0 \%$ & 20,353 & L5,00\% & $0,0,0 \%$ & $1500 \%$ & $19,53 \%$ \\
\hline 401.600 & $46,-61,4$ & 37 & |8991/2 & 368944 & $150,0 \%$ & $3500 \%$ & $30,7 \%$ & $30,95 \%$ & $2,1,27 \%$ & 23,080 & $13,00 \%$ & $30,7 \%$ & $386,66 \%$ & 1,7,55\% & $40,00 \%$ & 29,416 & L5,00\% & $0,0, \%$ & 218986 & 28991\% \\
\hline y01 & 9.5.4t,6 & 12 & $\mid 93800$ & $5,66 \%$ & $1667 \%$ & 13,330 & 15,398\% & 7,140 & 18,896 & $3,85 \%$ & $4,66 \%$ & $1,9 \% \%$ & $15398 \%$ & 58880 & $6,07 \%$ & $0,00 \%$ & $0,00 \%$ & $0,00 \%$ & $115,50 \%$ & 9,380 \\
\hline
\end{tabular}

In the case of metrics by SDG, they are classified into categories. Research metrics are the result of data provided by Elsevier's Scopus Database [12] [13] during the period 2014 to 2018. For each SDG, a specific query has been created that narrows the scope of the metric to papers relevant to that SDG. Continuous metrics measure contributions to impact that vary continually across a range. These are usually normalized to the size of the university. In the cases of policies and initiatives, metrics require supplying evidence on the part of this institution.

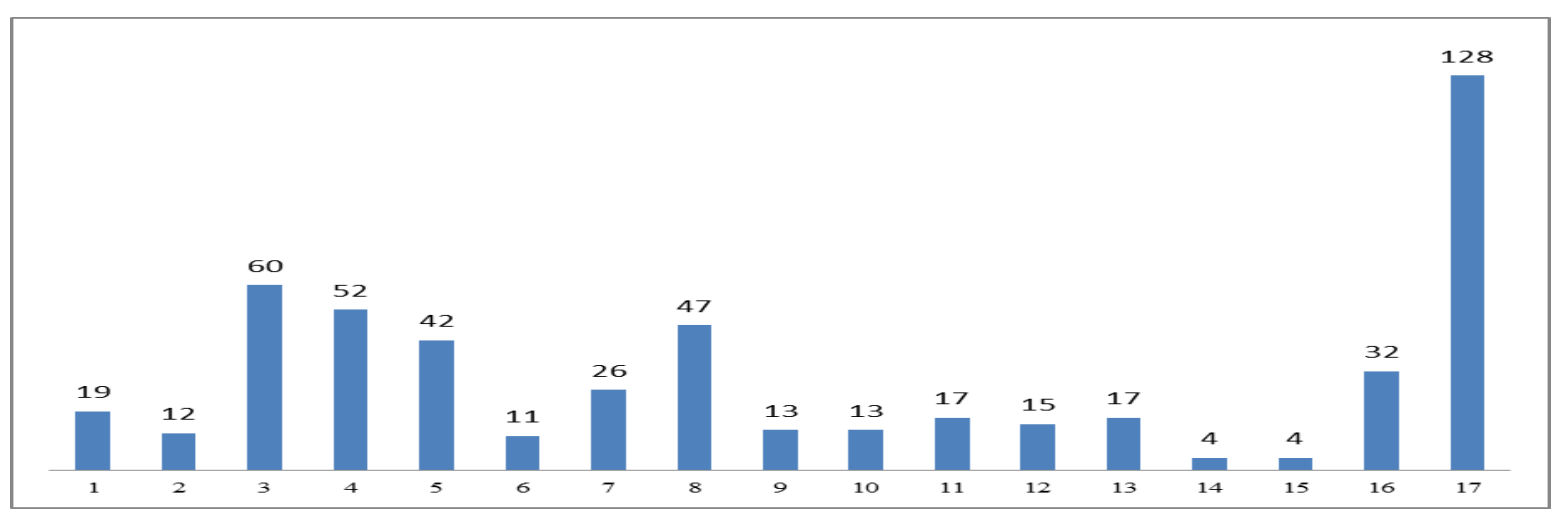

Fig. 1. Amount of best scores of Ibero-American universities in THE Impact Rankings 2020 by SDG [5] [8].

3. Comparison of indicators between universities in Top20 of THE World University Rankings 2020

Below is presented a descriptive analysis of Ibero-American universities in indicators related to 17 SDGs of UN in Times Higher Education Impact Rankings 2020 [8] [12]. Each university has an Overall value which places it in Rank.

3.1. Ibero-American universities classified by SDG 1: no poverty

SDG 1 - no poverty measures universities' research on poverty and their support for poor students and citizens in the local community [14]. In this goal are included 372 universities of the world, 19 of them are from Ibero-America (5.10\%).

Fig. 2 shows 36.84\% of Ibero-American universities with best scores by Rank in SDG 1 located in Rank 401600 [12] [14]. They are seven: Federal University of Mato Grosso do Sul (UFMS-BR), Federal Rural University of the Semi-Arid Region (UFERSA-BR), Federico Santa María Technical University (USM-CL), University of Montevideo (UM-UY), Pontifical Catholic University of Minas Gerais (PUC-MG-BR), Popular Autonomous University of the State of Puebla (UPAEP-MX) and Unisinos University (UNISINOS-BR). 
${ }^{1}$ Marisabel Luna Cardozo, ${ }^{2}$ Gregorio Arroyo Japura, ${ }^{3}$ Alfonso Renato Vargas-Murillo, ${ }^{4}$ Gerber F. Incacari Sancho, ${ }^{5}$ Hugo Ricardo Prado López

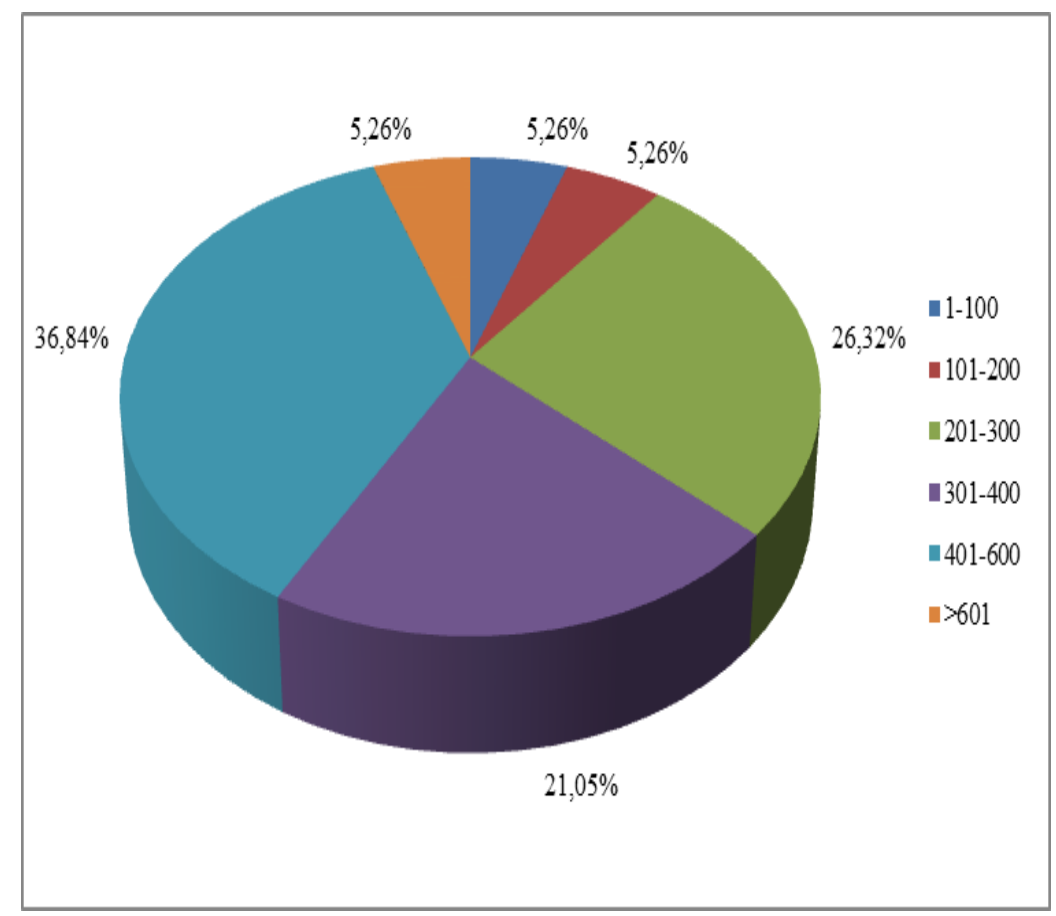

Fig 2. Percentage of Ibero-American universities with best scores by Rank in SDG 1: no poverty in THE Impact Rankings 2020 [12] [14].

\subsection{Ibero-American universities classified by SDG 2: zero hunger}

SDG 2 - zero hunger measures universities' research on hunger, their teaching on food sustainability and their commitment to tackle food waste and address hunger among students and local communities [15]. In this goal are included 290 universities of the world, 12 of them are Ibero-American $(4.13 \%)$.

Fig. 3 shows $33.33 \%$ of Ibero-American universities with best scores by Rank in SDG 2 located in Rank 201-300 [12] [15]. They are four: Federal University of Ceará (UFC-BR), Federal University of Santa Maria (UFSM-BR), Fluminense Federal University (UFF-BR) and University of Trás-os-Montes and Alto Douro (UTAD-PT).

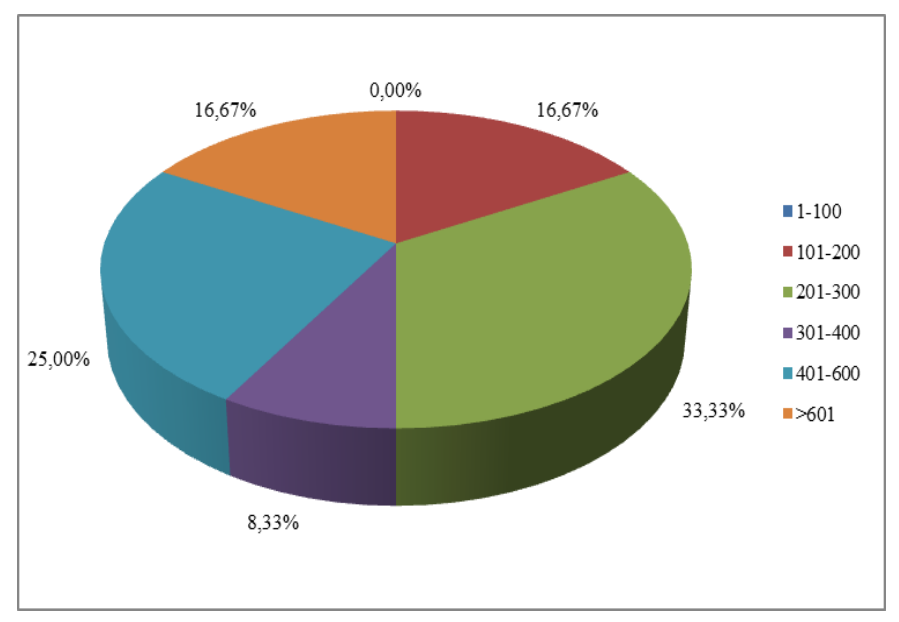

Fig. 3. Percentage of Ibero-American universities with best scores by Rank in SDG 2: zero hunger in THE Impact Rankings 2020 [12] [15].

\subsection{Ibero-American universities classified by SDG 3: good health and well-being}

SDG 3 - good health and well-being measures universities' research on key diseases and conditions, their support for healthcare professions, and the health of students and staff [16]. In this goal are included 620 universities of the world, 60 of them are Ibero-American (9.68\%).

Fig. 4 shows, in SDG 3, 35\% \% of Ibero-American universities with best scores are located in Rank 401-600 [12] [16]. They are twenty one: University of Alicante (UA-ES), Autonomous University of Baja California 
(UABC-MX), Autonomous University of the State of Mexico (UAEM-MX), University of Azuay(UAZUAYEC), Catholic University of the Most Holy Conception (UCSC-CL), Ceará State University (UECE-BR), EAN University (EAN-CO), Federal University of Mato Grosso do Sul (UFMS-BR), Federal University of Technology-Paraná (UTFPR-BR), University of La Laguna (ULL-ES), University of the North, Colombia (UNINORTE-CO), Peruvian University Cayetano Heredia (UPCH-PE), Peruvian University of Applied Sciences (UPC-PE), Pontifical Catholic University of Rio Grande do Sul (PUCRS-BR), Popular Autonomous University of the State of Puebla (UPAEP-MX), Public University of Navarre (UPNA-ES), University of La Serena (USERENA-CL), Espiritu Santo University (UEES-EC), Unisinos University (UNISINOS-BR), Vila Velha University (UVV-BR) and The University of the West Indies (UWI-JM).

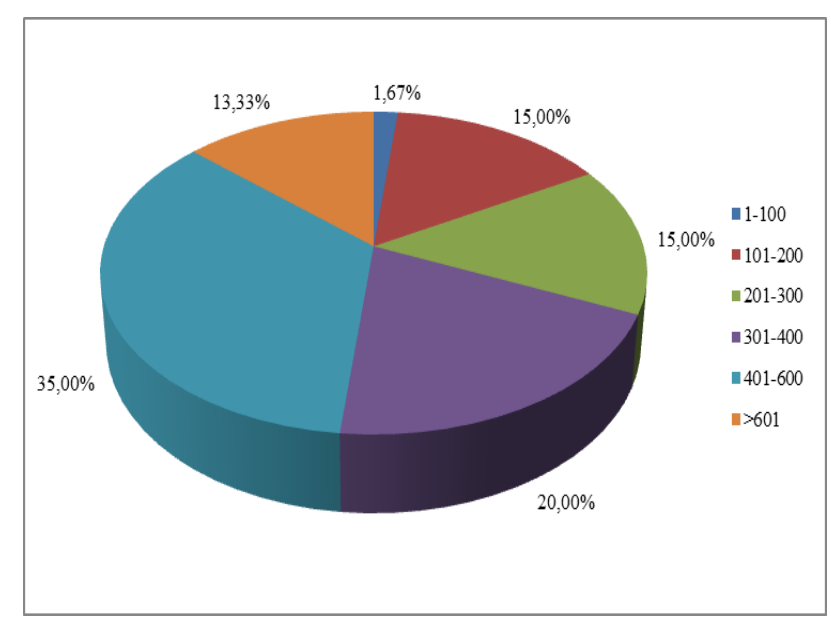

Fig. 4. Percentage of Ibero-American universities with best scores by Rank in SDG 3 - good health and wellbeing in THE Impact Rankings 2020 [12] [16].

\subsection{Ibero-American universities classified by SDG 4: quality education}

SDG 4 - quality education measures universities' contribution to early years and lifelong learning, their pedagogy research and their commitment to inclusive education [17]. In this goal are included 676 universities of the world, 52 of them are Ibero-American (7.69\%).

Fig. 5 shows $30.77 \%$ of Ibero-American universities with best scores by Rank in SDG 4 located in Rank 401-600 [12] [17]. They are sixteen: Adolfo Ibáñez University (UAI-CL), University of Alicante (UA-ES), Catholic University of the Most Holy Conception (UCSC-CL), Ceará State University (UECE-BR), Federal University of Mato Grosso do Sul (UFMS-BR), Federal University of Paraná (UFPR-BR), Federal University of Technology-Paraná (UTFPR-BR), Federico Santa María Technical University (USM-CL), University of Franca (UNIFRAN-BR), University of La Laguna (ULL-ES), University of Medellín (UDEM-CO), University of Montevideo (UM -UY), Peruvian University of Applied Sciences (UPC-PE), Pontifical Catholic University of Rio Grande do Sul (PUCRS-BR), Public University of Navarre (UPNA-ES) and University of La Serena (USERENA-CL).

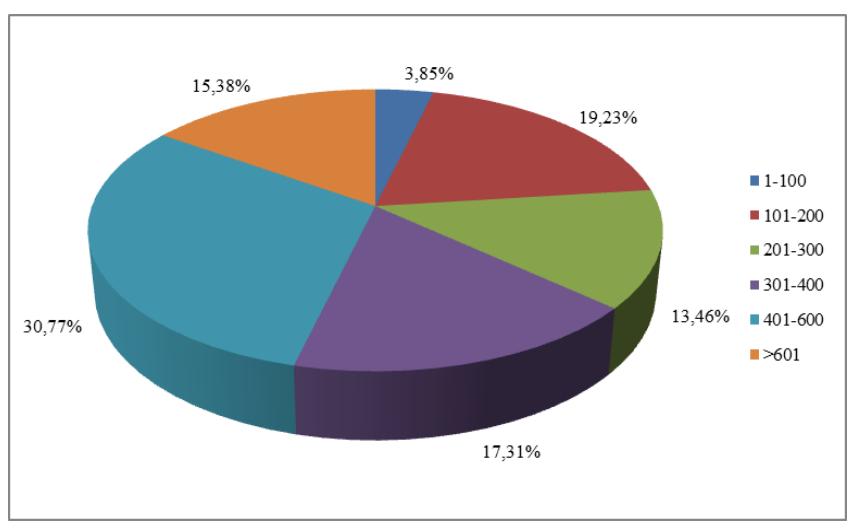

Fig. 5. Percentage of Ibero-American universities with best scores by Rank in SDG 4 - quality education in THE Impact Rankings 2020 [12] [17].

\subsection{Ibero-American universities classified by SDG 5: gender equality}

SDG 5 - gender equality measures universities' research on the study of gender, their policies on gender equality and their commitment and promoting [18]. In this goal are included 547 universities of the world, 42 of them are Ibero-American (7.68\%). 
${ }^{1}$ Marisabel Luna Cardozo, ${ }^{2}$ Gregorio Arroyo Japura, ${ }^{3}$ Alfonso Renato Vargas-Murillo, ${ }^{4}$ Gerber F. Incacari Sancho, ${ }^{5}$ Hugo Ricardo Prado López

Fig. 6 shows $30.95 \%$ of Ibero-American universities with best scores by Rank in SDG 5 located in Rank 401-600 [12] [18]. They are thirteen: Adolfo Ibáñez University (UAI-CL), University of Alicante (UA-ES), Autonomous University of San Luis Potosi (UASLP-MX), Autonomous University of the State of Mexico (UAEM-MX), Caribbean University (UNICARIBE-MX), Catholic University of the Most Holy Conception (UCSC-CL), University of la Costa (CUC-CO), ESIC Business and Marketing School (ESIC-ES), Federal University of Paraná (UFPR-BR), University of Franca (UNIFRAN-BR), University of Medellín (UDEM-CO), Peruvian University Cayetano Heredia (UPCH-PE) and The University of the West Indies (UWI-JM).

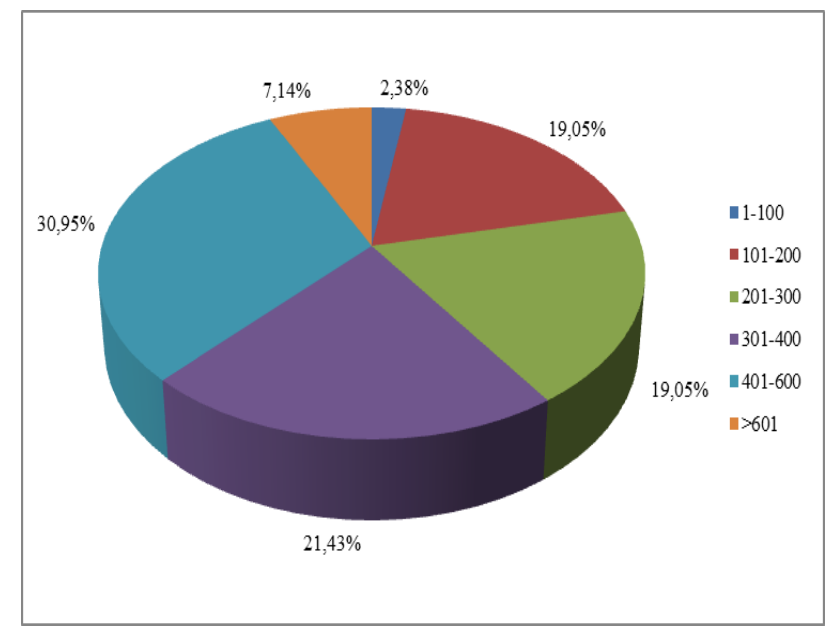

Fig. 6. Percentage of Ibero-American universities with best scores by Rank in SDG 5 - gender equality in THE Impact Rankings 2020 [12] [18].

\subsection{Ibero-American universities classified by SDG 6: clean water and sanitation}

SDG 6 - clean water and sanitation measures universities' research related to water, their water usage and their commitment to ensuring good water management in the wider community [19]. In this goal are included 330 universities of the world, 11 of them are Ibero-American (3.33\%).

Fig. 7 shows $27.27 \%$ of Ibero-American universities with best scores by Rank in SDG 6 located in Rank 401600 [12] [19]. They are three: Autonomous University of Nuevo León (UANL-MX), Federal University of Itajubá (UNIFEI-BR) and University of Medellín (UDEM-CO).

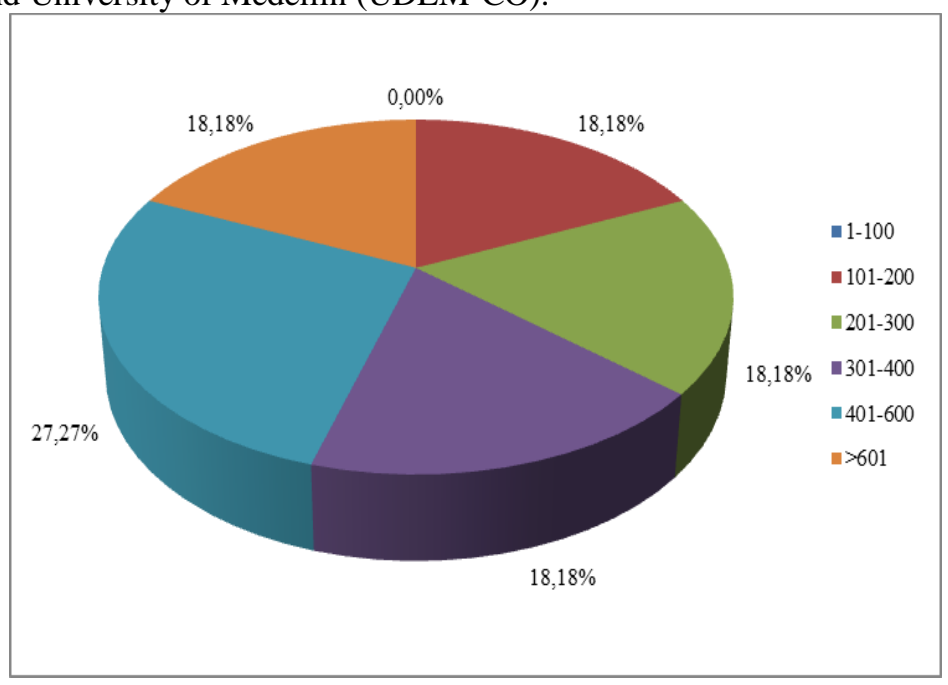

Fig. 7. Percentage of Ibero-American universities with best scores by Rank in SDG 6 - clean water and sanitation in THE Impact Rankings 2020 [12] [19].

\subsection{Ibero-American universities classified by SDG 7: affordable and clean energy}

SDG 7 - affordable and clean energy measures universities' research related to energy, their energy use and policies, and their commitment to promoting energy efficiency in the wider community [20]. In this goal are included 361 universities of the world, 26 of them are Ibero-American (7.20\%). 
Fig. 8 shows $23.08 \%$ of Ibero-American universities with best scores by Rank in SDG 7 located in Rank 401600 [12] [20]. They are six: Autonomous University of Nuevo León (UANL-MX), University of Azuay (UAZUAY-EC), Caribbean University (UNICARIBE- MX), Federal University of Paraná (UFPR-BR), Federal University of Piauí (UFPI-BR) and Peruvian University Cayetano Heredia (UPCH-PE).

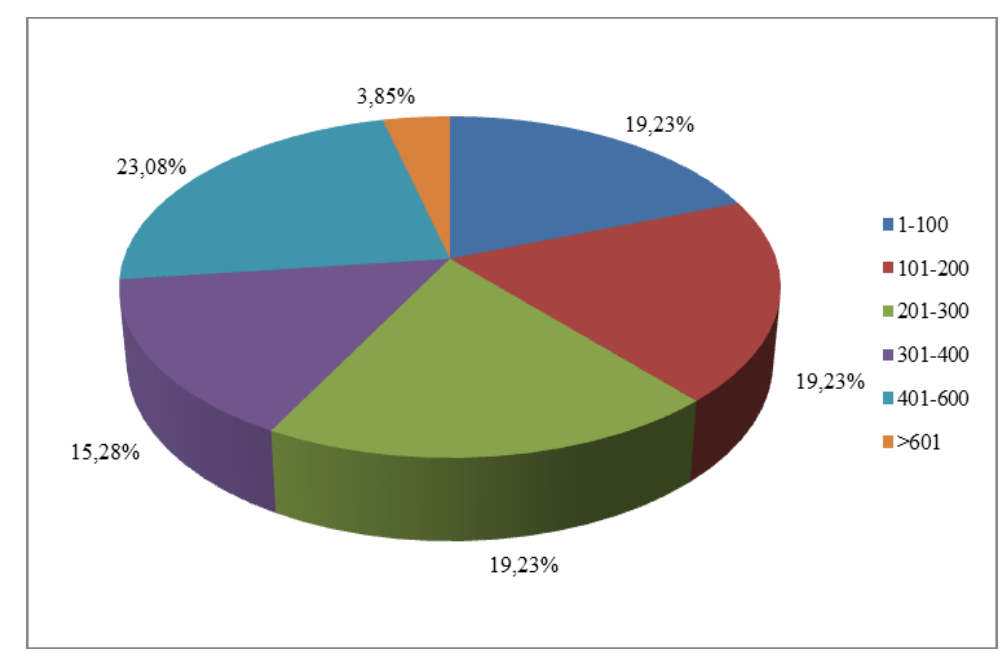

Fig. 8. Percentage of Ibero-American universities with best scores by Rank in SDG 7 - affordable and clean energy in THE Impact Rankings 2020 [12] [20].

\subsection{Ibero-American universities classified by SDG 8: decent work and economic growth}

SDG 8 - decent work and economic growth measures universities' economics research, their employment practices and the share of students taking work placements [21]. In this goal are included 479 universities of the world, 47 of them are Ibero-American $(9.81 \%)$.

Fig. 9 shows $23.40 \%$ of Ibero-American universities with best scores by Rank in SDG 8 located in Ranks 301-400 and 401-600 [12] [21]. In each Rank are located eleven universities. In Rank 301-400: Catholic University of Portugal (UCP-PT), University of Chile (UCHILE-CL), Comillas Pontifical University (COMILLAS-ES), Litoral Polytechnic School (ESPOL-EC), Federal University of Health Sciences of Porto Alegre (UFCSPA-BR), Federal University of Pernambuco (UFPE-BR), IE University (IE-ES), Simón Bolívar University (USB-CO), Technical University of Loja (UTPL-EC), Technological University of Pereira (UTP$\mathrm{CO}$ ), University of Valladolid (UVA-ES) and University of Valparaiso (VALPO-CL).

In Rank 401-600: Autonomous University of Baja California (UABC-MX), Caribbean University (UNICARIBE-MX), University of la Costa (CUC-CO), ESIC Business and Marketing School (ESIC-ES), Federal University of Itajubá (UNIFEI-BR), Federal Rural University of the Semi-Arid Region (UFERSA-BR), University of La Laguna (ULL-ES), Peruvian University of Applied Sciences (UPC-PE), Pontifical Catholic University of Minas Gerais (PUC-MG-BR), Popular Autonomous University of the State of Puebla (UPAEPMX) and Espiritu Santo University (UEES-EC).

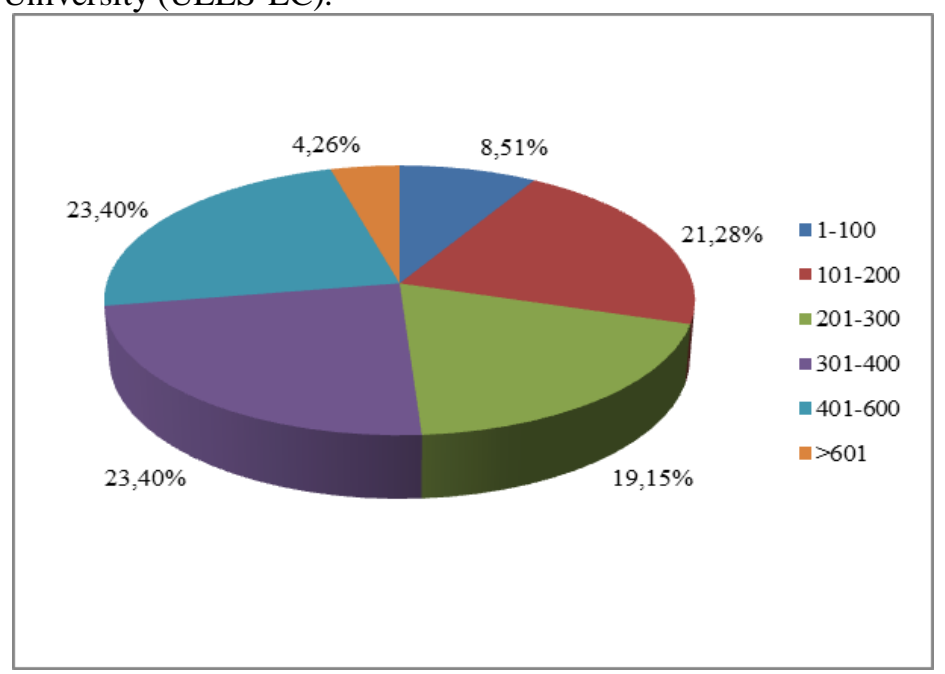

Fig. 9. Percentage of Ibero-American universities with best scores by Rank in SDG 8 - decent work and economic growth in THE Impact Rankings 2020 [12] [21]. 
${ }^{1}$ Marisabel Luna Cardozo, ${ }^{2}$ Gregorio Arroyo Japura, ${ }^{3}$ Alfonso Renato Vargas-Murillo, ${ }^{4}$ Gerber F. Incacari Sancho, ${ }^{5}$ Hugo Ricardo Prado López

\subsection{Ibero-American universities classified by SDG 9: industry, innovation and infrastructure}

SDG 9 - industry, innovation and infrastructure measure universities' research on industry and innovation, their number of patents and spin-off companies and their research income from industry [22]. In this goal are included 494 universities of the world, 13 of them are Ibero-American (2.63\%).

Fig. 10 shows $30.77 \%$ of Ibero-American universities with best scores by Rank in SDG 9 located in Ranks 101-200 and 401-600 [12] [22]. In each Rank are located four universities. In Rank 101-200: Miguel Hernández University of Elche (UMH-ES), University of Minho (UMINHO-PT), NOVA University of Lisbon (UNL-PT) and Polytechnic University of Valencia (UPV-ES). In Rank 401-600: Adolfo Ibáñez University (UAI-CL), University of la Costa (CUC-CO), Federal University of Technology-Paraná (UTFPR-BR) and Public University of Navarre (UPNA-ES).

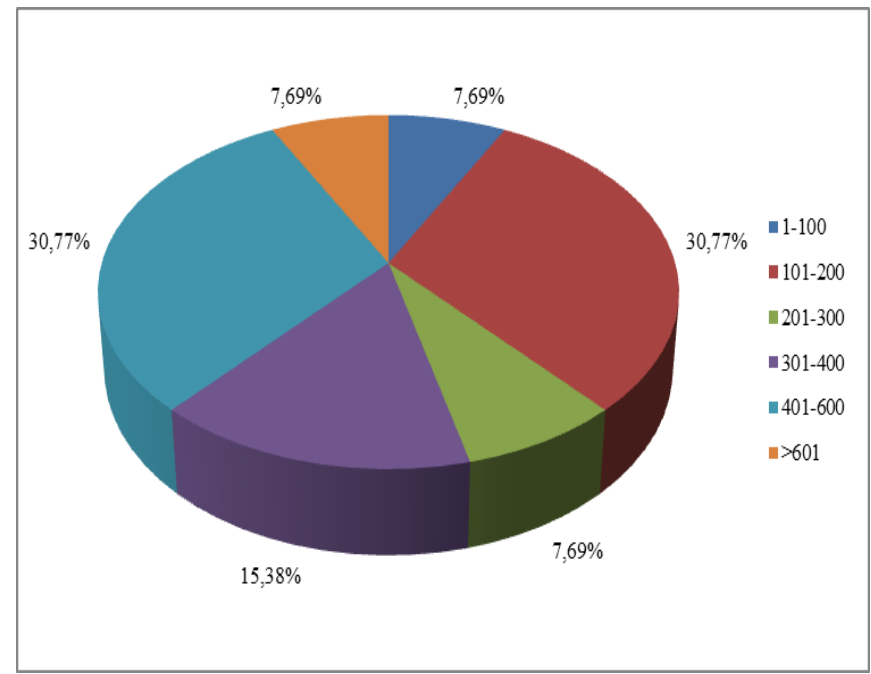

Fig. 10. Percentage of Ibero-American universities with best scores by Rank in SDG 9 - industry, innovation and infrastructure in THE Impact Rankings 2020 [12] [22].

\subsection{Ibero-American universities classified by SDG 10: reduced inequalities}

SDG 10 - reduced inequalities measures universities' research on social inequalities, their policies on discrimination and their commitment to recruiting staff and students from under-represented groups [23]. In this goal are included 458 universities of the world, 13 of them are Ibero-American (2.84\%).

Fig. 11 shows $38.46 \%$ of Ibero-American universities with best scores by Rank in SDG 10 located in Rank 401- 600 [12] [23]. They are five: Autonomous University of the State of Mexico (UAEM-MX), Ceará State University (UECE-BR), ESIC Business and Marketing School (ESIC-ES), Federico Santa María Technical University (USM-CL) and University of Franca (UNIFRAN-BR).

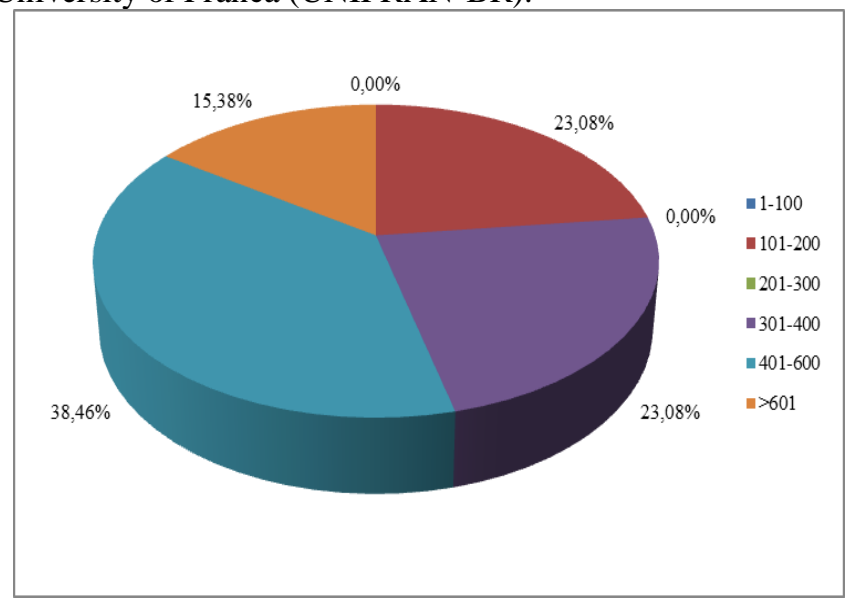

Fig. 11. Percentage of Ibero-American universities with best scores by Rank in SDG 10 - reduced inequalities in THE Impact Rankings 2020 [12] [23].

\subsection{Ibero-American universities classified by SDG 11: sustainable cities and communities}

SDG 11 - sustainable cities and communities measures universities' research on sustainability, their role as custodians of arts and heritage and their internal approaches to sustainability [24]. In this goal are included 470 universities of the world, 17 of them are Ibero-American (3.61\%). 
Fig. 12 shows $35.29 \%$ of Ibero-American universities with best scores by Rank in SDG 11 located in Rank 101-200 [12] [24]. They are six: EAFIT University (EAFIT-CO), University of Girona (UDG-ES), Monterrey Institute of Technology (ITESM-MX), University of Murcia (UM-ES), University of Navarra (UNAV-ES) and University of Vigo (UVIGO-ES).

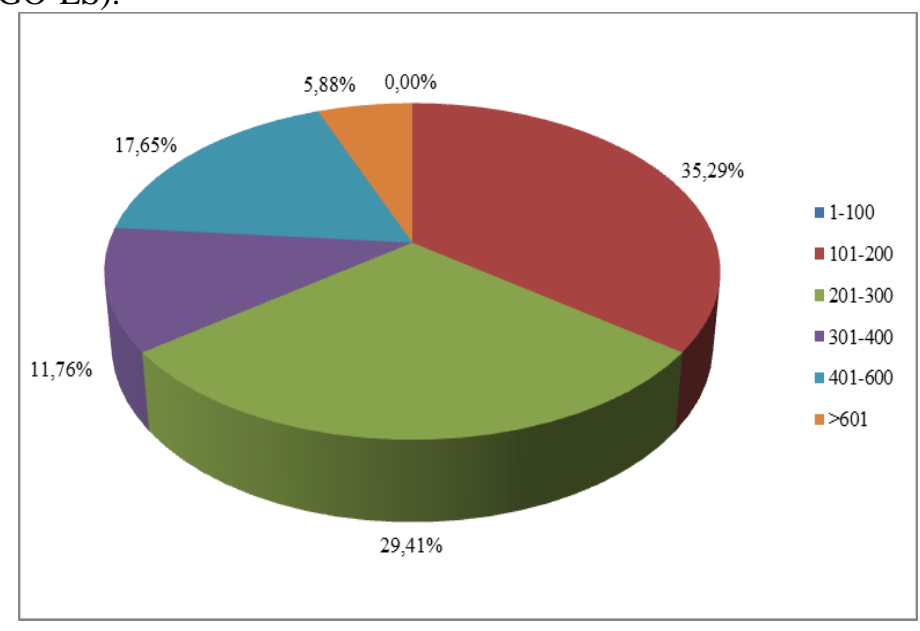

Fig. 12. Percentage of Ibero-American universities with best scores by Rank in SDG 11 - sustainable cities and communities in THE Impact Rankings 2020 [12] [24].

3.12. Ibero-American universities classified by SDG 12: responsible consumption and production

SDG 12 - responsible consumption and production measures universities' research on responsible consumption and their approach to the sustainable use of resources [25]. In this goal are included 360 universities of the world, 15 of them are Ibero-American (4.17\%).

Fig. 13 shows $40 \%$ of Ibero-American universities with best scores by Rank in SDG 12 located in Rank 401600 [12] [25]. They are six: Autonomous University of Nuevo León (UANL-MX), Autonomous University of San Luis Potosi (UASLP-MX), EAN University (EAN-CO), University of the North, Colombia (UNINORTE$\mathrm{CO}$ ), University of Puerto Rico (UPR-PR) and Unisinos University (UNISINOS-BR).

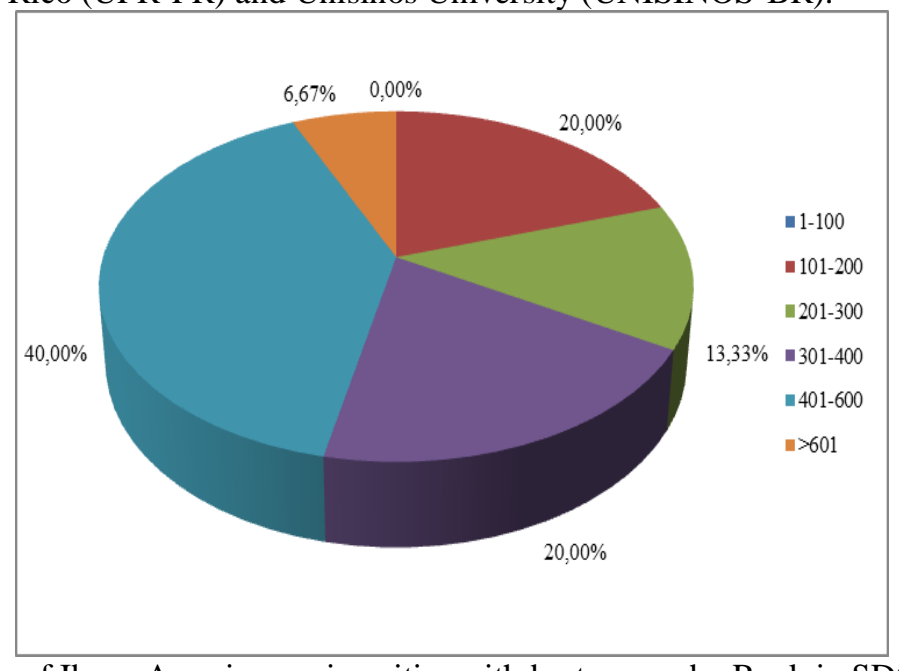

Fig. 13. Percentage of Ibero-American universities with best scores by Rank in SDG 12 - responsible consumption and production in THE Impact Rankings 2020 [12] [25].

\subsection{Ibero-American universities classified by SDG 13: climate action}

SDG 13 - climate action measures universities' research on climate change, their use of energy and their preparations for dealing with the consequences of climate [26]. In this goal are included 376 universities of the world, 17 of them are Ibero-American (4.52\%).

Fig. 14 shows $29.41 \%$ of Ibero-American universities with best scores by Rank in SDG 13 located in Ranks 101-200 and 401-600 [12] [26]. In each Rank are five universities. In Rank 101-200: Autonomous University of Barcelona (UAB-ES), CES University (CES-CO), EAFIT University (EAFIT-CO), University of Valencia (UVES) and University of Zaragoza (UNIZAR-ES). In Rank 401-600: EAN University (EAN-CO), Federal University of Itajubá (UNIFEI-BR), Federal University of Piauí (UFPI-BR), University of La Serena (USERENA-CL) and The University of the West Indies (UWI-JM). 
${ }^{1}$ Marisabel Luna Cardozo, ${ }^{2}$ Gregorio Arroyo Japura, ${ }^{3}$ Alfonso Renato Vargas-Murillo, ${ }^{4}$ Gerber F. Incacari Sancho, ${ }^{5}$ Hugo Ricardo Prado López

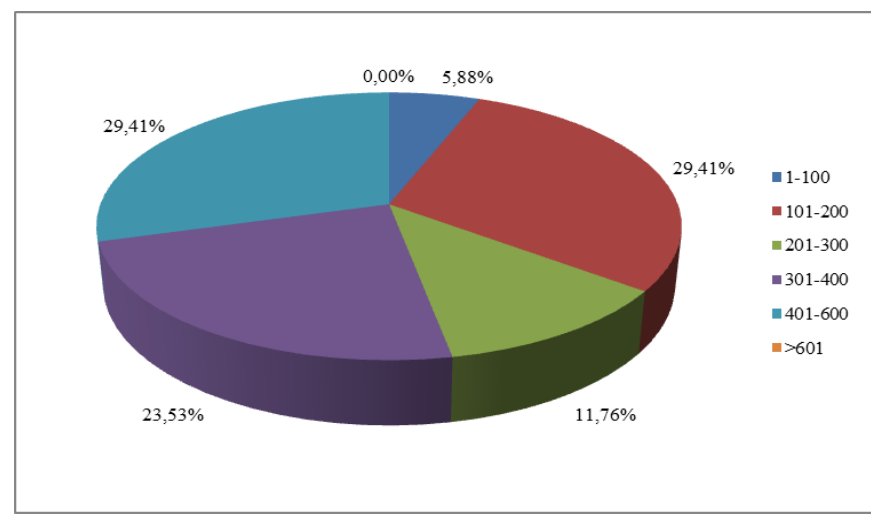

Fig. 14. Percentage of Ibero-American universities with best scores by Rank in SDG 13 - climate action in THE Impact Rankings 2020 [12] [26].

\subsection{Ibero-American universities classified by SDG 14: life bellow water}

SDG 14 - life bellow water measures universities' research on life bellow water and their education on and support for aquatic ecosystems [27]. In this goal are included 242 universities of the world, 4 of them are IberoAmerican (1.65\%).

Fig. 15 shows $25 \%$ of Ibero-American universities with best scores by Rank in SDG 14 located in Ranks 1100, 201-300, 301-400 and 401-600 [12] [27]. In each Rank is one university. In Rank 1-100: University of Malaga (UMA-ES). In Rank 201-300: Andrés Bello University (UNAB-CL). En el Rank 301-400: National Agrarian University La Molina (LAMOLINA-PE). In Rank 401-600: Vila Velha University (UVV-BR).

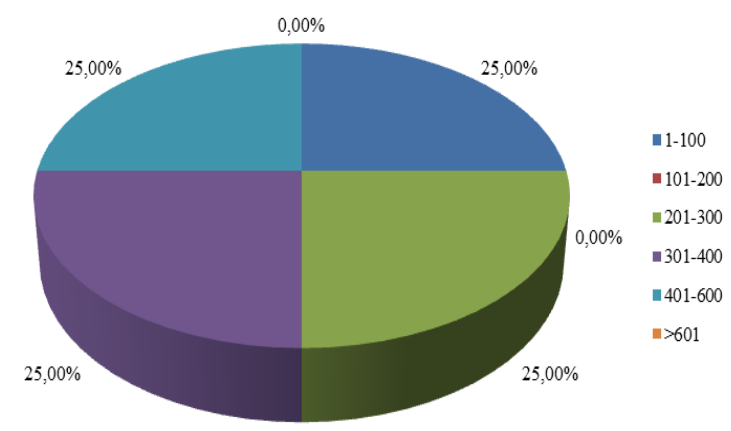

Fig. 15. Percentage of Ibero-American universities with best scores by Rank in SDG 14 - life bellow water in THE Impact Rankings 2020 [12] [27].

\subsection{Ibero-American universities classified by SDG 15: life on land}

SDG 15 - life on land measures universities' research on life on land and their education on and support for land ecosystems [28]. In this goal are included 268 universities of the world, 4 of them are Ibero-American $(1.49 \%)$.

Fig. 16 shows $50 \%$ of Ibero-American universities with best scores by Rank in SDG 15 located in Ranks 101200 [12] [28]. They are two: EAFIT University (EAFIT-CO) and State University of Maringá (UEM-BR).

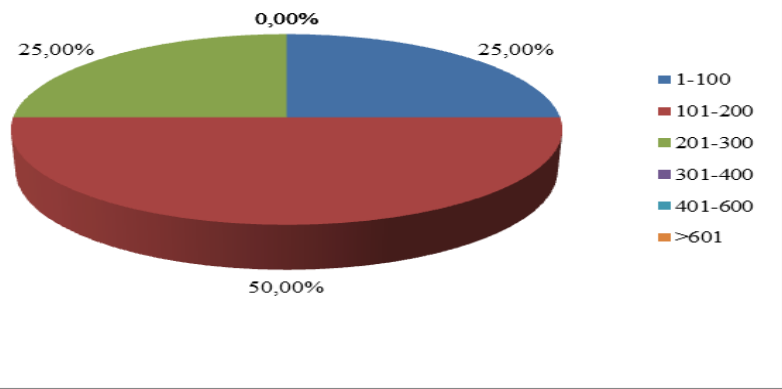

Fig. 16. Percentage of Ibero-American universities with best scores by Rank in SDG 15 - life on land in THE Impact Rankings 2020 [12] [28]. 
3.16. Ibero-American universities classified by SDG 16: peace, justice and strong institutions

SDG 16 - peace, justice and strong institutions measures universities' research on law and international relations, their participation as advisers for government and their policies on academic freedom [29]. In this goal are included 453 universities of the world, 32 of them are Ibero-American (7.06\%).

Fig. 17 shows 25\% of Ibero-American universities with best scores by Rank in SDG 16 located in Ranks 301400 [12] [29]. They are eight: Autonomous University of Chile (UATONOMA-CL), Autonomous University of Hidalgo State (UAEH-MX), Catholic University of Portugal (UCP-PT), Diego Portales University (UDP-CL), Pontifical Javeriana University (PUJ-CO), University of San Martín de Porres (USMP-PE), University of Santiago, Chile (USACH-CL) and Simón Bolívar University (USB-CO).

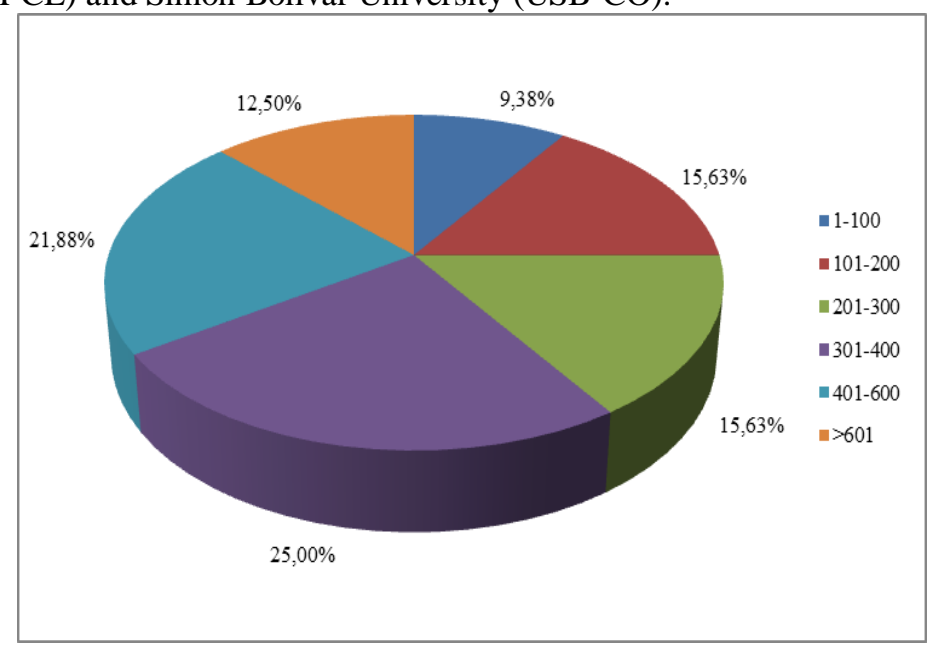

Fig. 17. Percentage of Ibero-American universities with best scores by Rank in SDG 16 - peace, justice and strong institutions in THE Impact Rankings 2020 [12] [29].

\subsection{Ibero-American universities classified by SDG 17: partnerships for the goals}

SDG 17 - partnerships for the goals looks at the broader ways in which universities support the SDGs through collaboration with other countries, the promotion of best practices and the publication of data [13]. In ranking data appears a vagueness: on one side in [5] 768, and in [13] 806 universities of the world, 128 of them are Ibero-American (16.67\%) adopting the first value as a reference.

Fig. 18 shows 5.47\% of Ibero-American universities with best scores by Rank in SDG 17 located in Top100. In Rank 101-200, 19.53\%. In Rank 201-300, 17.19\%. In Rank 301-400, 19.53\%. In Rank 401-600, $28.91 \%$. In Rank $+601,9.38 \%$. Shown values match with Table $1[5][8]$.

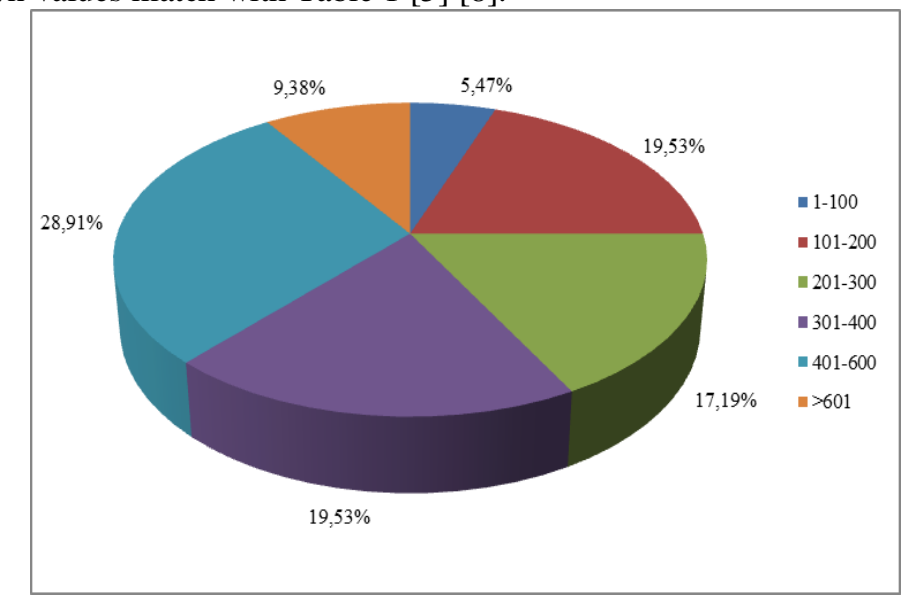

Fig. 18. Percentage of Ibero-American universities with best scores by Rank in SDG 17 - partnerships for the goals in THE Impact Rankings 2020 [8] [12] [13].

\section{Conclusions}

University rankings predominantly classify universities by their production and scientific dissemination. In that sense, Times Higher Education Impact Rankings organizes universities in respect to compliance metrics related with research, outreached and stewardship of SDGs. 2020 edition included 768 or 806 universities in the world, 128 of them are Ibero-American divided in different ranks from Top100 to +601. In this paper, universities has been analyzed and compared, through a descriptive analysis, in order to contrast performance of 
the institutions by SDG. As a result highlights a participation of $16.67 \%$ of Ibero-American universities in Ranking and in SDG 17. In SDG 8 - decent work and economic growth is a highest percentage of participation of Ibero-American universities: 9.81\%, there are included 479 universities of the world, 47 of them are IberoAmerican. In second place SDG: 3 - good health and well-being has a participation of Ibero-American universities of $9.68 \%$ (from 620 universities in the world, 60 are Ibero-American). In third place, in SDG 4 quality education is a participation of $7.69 \%$ of Ibero-American universities (from 676 universities in the world, 52 are Ibero-American).

\section{References}

1. C. Vásquez and M. Torres-Samuel, «Public policies in science and technology in latin American countries with universities in the top100 of web ranking,» Journal of engineering and applied science, 2017.

2. M. Torres-Samuel, C. Vásquez, M. Luna, N. Bucci, A. Viloria and J. Vargas, Characterization of Latin American Universities in the TOP10 of the Rankings. Proceedings of 6th International Conference on Big Data and Cloud Computing Challenges pp 105-118. https://link.springer.com/chapter/10.1007/978981-32-9889-7_9, 2019.

3. C. Vásquez and M. Torres-Samuel, «Public policies in science and technology in latin American countries with universities in the top100 of web ranking,» Journal of engineering and applied science, 2017.

4. M. Torres-Samuel, C. Vásquez, M. Luna, N. Bucci, A. Viloria and J. Vargas, Characterization of Latin American Universities in the TOP10 of the Rankings. Proceedings of 6th International Conference on Big Data and Cloud Computing Challenges pp 105-118. https://link.springer.com/chapter/10.1007/978981-32-9889-7_9, 2019.

5. Times Higher Education (THE), THE Impact Rankings 2020: results announced, Available in: https://www.timeshighereducation.com/news/impact-rankings-2020-results-announced, [Last access: 02 09 2020].

6. Times Higher Education (THE), Worl University Rankings, Available in: https://www.timeshighereducation.com/world-university-rankings\#, [Last access: 0309 2020].

7. Times Higher Education (THE), THE World University Rankings 2020: methodology, Available e in: https://www.timeshighereducation.com/world-university-rankings/world-university-rankings-2020methodology, [Last access: 0309 2020].

8. Times Higher Education (THE), Impact Rankins 2020, Available in: https://www.timeshighereducation.com/rankings/impact/2020/overall\#!/page/0/length/25/sort_by/rank/s ort_order/asc/cols/undefined, [Last access: 3008 2020].

9. United Nations, 17 goals to transform our world, Sustainable Development Goals, https://www.un.org/sustainabledevelopment/, [Last access: 02 09 2020].

10. J. Álvarez, I. Rios and E. Martínez, Comparative analysis of variables and indicators used to evaluate quality in the universities, Revista Humanidades Medicas, vol.19 no.2, Ciudad de Camaguey, mayo.ago. 2019, Epub 12-Ago-2019, Available in: http://scielo.sld.cu/scielo.php?script=sci_arttext\&pid=S1727-81202019000200405, [Last access: 2808 2020], 2020.

11. C. Vásquez, M. Luna, M. Torres-Samuel, N. Bucci, A. Viloria y T. Crissien, Producción científica y posicionamiento de universidades según ranking SIR IBER 2013 al 2019, caso latinoamericano. Iberia Journal of Information Systems and Technologies (RISTI). RISTI No E29, 05/2020. P.P. 570-581. ISSN: 1646-9895 http://www.risti.xyz/issues/ristie29.pdf, 2020.

12. Times Higher Education (THE), THE Impact Rankins 2020: methodology, https://www.timeshighereducation.com/university-impact-rankings-2020-methodology, [Last access: 30 08 2020].

13. Times Higher Education (THE), Impact Rankins 2020: partnerships for the goals, Available in: https://www.timeshighereducation.com/rankings/impact/2020/partnershipsgoals\#!/page/0/length/25/sort_by/rank/sort_order/asc/cols/undefined, [Last access: 0209 2020].

14. ELSEVIER, «Scopus Preview,» ELSEVIER BV, Available in: https://www.Scopus.com/home.uri. [Last access: 2908 2020].

15. Times Higher Education (THE), Impact Rankins 2020: no poverty, Available in: https://www.timeshighereducation.com/rankings/impact/2020/nopoverty\#!/page/0/length/25/sort_by/rank/sort_order/asc/cols/undefined, [Last access: 0209 2020].

16. Times Higher Education (THE), Impact Rankins 2020: zero hunger, Available in: https://www.timeshighereducation.com/rankings/impact/2020/zero-

hunger\#!/page/0/length/25/sort_by/rank/sort_order/asc/cols/undefined, [Last access: 0209 2020]. 
17. Times Higher Education (THE), Impact Rankins 2020: good health and well-being, Available in: https://www.timeshighereducation.com/rankings/impact/2020/good-health-and-wellbeing\#!/page///length/25/sort_by/rank/sort_order/asc/cols/undefined, [Last access: 0209 2020].

18. Times Higher Education (THE), Impact Rankins 2020: quality education, Available in: https://www.timeshighereducation.com/rankings/impact/2020/qualityeducation\#!/page/0/length/25/sort_by/rank/sort_order/asc/cols/undefined [Last access: 0209 2020].

19. Times Higher Education (THE), Impact Rankins 2020: gender equality, Available in: https://www.timeshighereducation.com/rankings/impact/2020/gender-

equality\#!/page/0/length/25/sort_by/rank/sort_order/asc/cols/undefined, [Last access: 0209 2020].

20. Times Higher Education (THE), Impact Rankins 2020: clean water and sanitation, Available in: https://www.timeshighereducation.com/rankings/impact/2020/clean-water-andsanitation\#!/page/0/length/25/sort_by/rank/sort_order/asc/cols/stats, [Last access: 0209 2020].

21. Times Higher Education (THE), Impact Rankins 2020: affordable and clean energy, Available in: https://www.timeshighereducation.com/rankings/impact/2020/affordable-and-cleanenergy\#!/page/0/length/25/sort_by/rank/sort_order/asc/cols/undefined, [Last access: 0209 2020].

22. Times Higher Education (THE), Impact Rankins 2020: decent work and economic growth, Available in: https://www.timeshighereducation.com/rankings/impact/2020/decent-work-and-economicgrowth\#!/page///length/25/sort_by/rank/sort_order/asc/cols/undefined, [Last access: 0209 2020].

23. Times Higher Education (THE), Impact Rankins 2020: industry, innovation and infrastructure, Available in: https://www.timeshighereducation.com/rankings/impact/2020/industry-innovation-andinfrastructure\#!/page/0/length/25/sort_by/rank/sort_order/asc/cols/stats, [Last access: 0209 2020].

24. Times Higher Education (THE), Impact Rankins 2020: reduced inequalities, Available in: https://www.timeshighereducation.com/rankings/impact/2020/reducinginequalities\#!/page/0/length/25/sort_by/rank/sort_order/asc/cols/undefined, [Last access: 02 09 2020].

25. Times Higher Education (THE), Impact Rankins 2020: sustainable cities and communities, Available in: $\quad$ https://www.timeshighereducation.com/rankings/impact/2020/sustainable-cities-andcommunities\#!/page/0/length/25/sort_by/rank/sort_order/asc/cols/undefined, [Last access: 02 09 2020].

26. Times Higher Education (THE), Impact Rankins 2020: responsible consumption and production, Available in: https://www.timeshighereducation.com/rankings/impact/2020/responsible-consumptionand-production\#!/page/0/length/25/sort_by/rank/sort_order/asc/cols/undefined, [Last access: 0209 2020].

27. Times Higher Education (THE), Impact Rankins 2020: climate action, Available in: https://www.timeshighereducation.com/rankings/impact/2020/climateaction\#!/page/0/length/25/sort_by/rank/sort_order/asc/cols/undefined, [Last access: 0209 2020].

28. Times Higher Education (THE), Impact Rankins 2020: life bellow water, Available in: https://www.timeshighereducation.com/rankings/impact/2020/life-below-

water\#!/page/0/length/25/sort_by/rank/sort_order/asc/cols/undefined [Last access: 0209 2020].

29. Times Higher Education (THE), Impact Rankins 2020: life on land, Available in: https://www.timeshighereducation.com/rankings/impact/2020/lifeland\#!/page/0/length/25/sort_by/rank/sort_order/asc/cols/undefined, [Last access: 0209 2020].

30. Times Higher Education (THE), Impact Rankins 2020: peace, justice and strong institutions, Available in: $\quad$ https://www.timeshighereducation.com/rankings/impact/2020/peace-justice-and-stronginstitutions\#!/page/0/length/25/sort_by/rank/sort_order/asc/cols/undefined, [Last access: 0209 2020]. 